\title{
Two Kingdoms, One King: The Treaty of Troyes (1420) and the Creation of a Double Monarchy of England and France
}

\author{
Anne Curry
}

Henry VI was crowned king of England at Westminster Abbey on 6 November 1429, exactly a month before his eighth birthday. Just over two years later, on 16 December 1431, shortly after he turned ten, he was crowned king of France at Notre Dame de Paris. His dual kingship goes back further: He had inherited his English kingdom at the death of his father, Henry V, on 31 August 1422. At this point he was just under nine months old, the youngest monarch ever to accede to the English throne. Six weeks later, on 22 October 1422, at the death of his maternal grandfather, Charles VI, he became king of France. He was not the youngest king of France, since John I was king from the day he was born (13 November 1316) until his death five days later. But was Henry VI king of France at all? He does not feature in French regnal lists or tables of succession. They have it that at the death of Charles VI, the Dauphin Charles (b. 1403) succeeded to his father's throne at the ripe old age of 19, being known subsequently as Charles VII and being crowned at Reims on 17 July 1429. His succession is based on his blood right as the direct male heir of his father - the standard form of inheritance in both French and English succession practice.

On the face of it, Henry VI had become king of France by virtue of a treaty - the treaty of Troyes of 21 May 1420 made between Henry V and Charles VI. ${ }^{1}$ By this, Charles was to remain king for his lifetime and enjoy all the rights and dignity of that position (cl. 2). But at his death, the crown and realm of France with all its rights and appurtenances was to go to, and to remain with in perpetuity, King Henry and his heirs (cl. 6). This was further elaborated in clause 24. Once Henry V came to the French throne, the two crowns of England and France were to remain together and under the same person, namely Henry V while he lived, and after him 'his heirs who arise successively, one after the other' (ses hoirs qui successivement seront les uns après les autres). In other words, from the death of Charles VI onwards, there would be what historians have called 'a double monarchy' - two kingdoms but one ruler.

1 I have used the French text and the numbering of clauses as given in Eugene Cosneau, Les grandes traités de la guerre de Cent Ans (Paris, 1889), pp. 102-15, which derives from the official versions in Paris, Archives Nationales Xia 8603 (ordonnances royales) and JJ171 (trésor des chartes). A translation into English is provided at the end of this chapter.

2 Contemporaries did not employ this term but rather 'l'union des deux couronnes': André Bossuat, 'Le parlement de Paris pendant l'occupation anglaise', Revue historique, 229 
Clause 22 of the treaty established Henry V's title while Charles lived: 'Our dear son, King of England, and Heir (héritier) of France'. He was not to call himself king of France. Yet that was a title which he had taken up at his accession to the English throne in 1413 as the inheritor of the claim to the crown of France first made by Edward III over 70 years earlier. Edward argued that as nephew of Charles IV (d. 1328) he was closer in blood, through the female line, to the late king than the cousin through male descent who succeeded to the throne as Philip VI. Historians have long debated the reasons for, and the seriousness of, Edward III's claim. ${ }^{3}$ There is no doubt, however, that he formally assumed the title 'king of France' in Ghent in January 1340, and that this had contributed greatly to Anglo-French conflict in the years which followed. Although Edward had agreed at the treaty of Brétigny in 1360 to give up the title in return for an advantageous territorial settlement, he had resumed it in 1369 when the French reneged upon the deal. Ever since, English kings had called themselves king of France. It was under colour of that title that Henry V had invaded France in 1415 and 1417, and in all of his dealings with the French he had called himself king of France and of England. Important issues are therefore raised by this change in Henry V's title in 1420. Was the 'heirship' which Henry now held an acknowledgement of the validity of his earlier claim to the French throne, and by implication that of his predecessors from Edward III onwards? Or was it a new right created by the treaty of Troyes? This issue was, I think, kept deliberately vague in the treaty since in both interpretations it threatened to undermine the authority of Charles VI who had made the treaty as 'king of France', a title Henry V had hitherto refused to accord to him.

Although some contemporary English commentators describe the heirship as deriving from Henry's descent from Edward III, ${ }^{4}$ there is no mention of this English hereditary claim to France in the treaty itself. Its preamble speaks of the failure of treaties made in the past between the predecessors of both Henry and Charles as well as between themselves to bring about peace and remove dissension between the two kingdoms of France and England. Now, mindful of the evils and sorrows which had been caused by the division of the two kingdoms, not simply for the kingdoms themselves but also for the whole church militant, Charles had come to peace with Henry. This, the preamble states, both met the French king's wishes and promised peace to all men of good will. The terms of the agreement then follow. Interestingly Henry is described in this preamble as 'king of England, heir of France'. In other words, he was already heir to Charles rather than being given this position by the treaty. This could suggest that Henry's heirship derived from a Roman-style adoption

(1963): $19-40$ at p. 20, cited in C.A.J. Armstrong, 'La double monarchie France-Angleterre et la maison de Bourgogne (1420-1435). Le déclin d'une alliance', Annales de Bourgogne, 37 (1965): 81-112 at p. 81 reprinted in C.A.J. Armstrong, England, France and Burgundy in the Fifteenth Century (London, 1983), p. 343.

3 Anne Curry, The Hundred Years War 2nd edn (Basingstoke, 2003), pp. 38-50.

4 'proclaymed was then of fraunce regent, and heritour of Fraunce by right lyne, of his owne right fro kyng Edwares discent, and Normandy and Guyan as appent, remain should to hym and to his heyres, Kynges of Englande evermore, and to theryrs': John Hardyng, Chronicle from the earliest period of English history (to 1461), together with the Continuation by Richard Grafton to 34 Henry VIII ed. H. Ellis (London, 1812), p. 379. 
by Charles which preceded the sealing of the treaty, but there is no evidence for this and it is a very dubious notion.

It can be argued, however, that Henry's description as heir was an admission of the rightness of the English claim to the French throne, and in that important respect a master stroke for English diplomacy. The terms which follow in the rest of the treaty are simply how the transfer of authority was to be effected in a way which preserved the French monarchy intact for Henry to inherit in due course - by right and not by conquest. The heirship fortified his claim. Just as Henry had to accept Valois kingship to be its heir, so the French had to accept Henry's own ancestral right to the French inheritance. Nowhere is this better exemplified than in the fact that Henry did not choose to continue his use of the title duke of Normandy, even though he had been calling himself this since he began his campaign of conquest in August 1417. As heir to the French throne, he wanted the duchy reunited with the crown once Charles VI died and he became king. By the time the treaty was sealed Normandy lay almost wholly under English occupation. The wording of the relevant clause (cl. 18) implicitly preserved that position until his accession. In the meantime Henry did not want any suspicion that he was holding Normandy by virtue of separate claims derived from his predecessors as kings of England and dukes of Normandy. Normandy was his because the whole of France was his, by inheritance from Edward III's right to the French, as well as the English throne.

In this context we might perhaps have expected Henry to take the title Dauphin. The problem here was that the title derived from tenure of the Dauphine by royal grant. At the time of the sealing of the treaty, the Dauphin Charles still held the territory although the text referred to him as 'soy disant Daulphin de Viennois'. It was not until January 1421, when he failed to respond to a legal summons issued by a royal lit de justice of December 1420, that he was formally deprived of all his lands, rights and titles. ${ }^{5}$ At that point, Henry could have been granted the territory of Dauphiné and hence the title, yet he was not. In 1435 lawyers at Bologna, in response to approaches from the Burgundians now keen to drop their English alliance, advised that once Charles VI had bestowed the Dauphiné on Dauphin Charles in 1417, the latter was bound to inherit the kingdom of France. ${ }^{6}$ However, the tenure of this area was not in French law a qualification or a prerequisite for kingship any more than the holding of the principality of Wales, earldom of Chester or duchy of Cornwall were pre-requisites for English kingship. To have made Henry V Dauphin might also have placed him on a par with the so-called Dauphin Charles. As the specifically designated 'heir' of Charles VI his superior position could not be questioned.

5 Gaston du Fresne de Beaucourt, Histoire de Charles VII (six vols, Paris, 1881-91), vol. 1, p. 217. This had been anticipated a year previously when, on 17 January 1420 , letters were issued in the name of Charles VI forbidding the inhabitants of Paris from communication with the Dauphin and ordering them to refuse him obedience as he had rendered himself unworthy of succession to the throne and to all other honours and dignities (ibid., p. 196, from Ordonnances des rois de France de la troisième race (22 vols, Paris, 1723-1846), vol. 12, pp. 273-7).

6 Malcolm G.Vale, Charles VII (Berkeley, 1974), p. 32, from Dom Urbain Plancher, Histoire générale et particulière de la Bourgogne (four vols, Dijon, 1739-81), vol. 4, no. 122, pp. cli-clvii. 
It appears, therefore, that the treaty of Troyes was skilfully worded to fudge the past. The English claim to France was acknowledged but without the French having to admit that they had spent the last 80 years with the wrong king. In terms of realpolitik, therefore, Henry V had a much better chance of becoming king of France than his predecessors since his right had been fully accepted by the man the French recognised as their king. The oaths required by clause 13 of the treaty obliged the French to accept and obey Henry as 'their liege lord and sovereign and true king of France, without any opposition, contradiction or difficulty', and in the meantime to obey no one other than the king himself and Henry as his heir. We might ponder what might have happened had Henry V outlived Charles VI. But despite being 20 years younger, he died first. Thus it was the infant Henry VI, as we have seen, who became the first (and in reality only) king of the double monarchy of England and France envisaged by the treaty. But what kind of double monarchy was it? It is important to remember that it was, as in 1603, a 'union of two crowns', not a union of two countries. It did, however, lay down in clause 25 that 'from this point onwards and forever more ... all dissensions, hatreds, rancours, and conflict between the two kingdoms and their peoples should cease ... with peace, tranquillity, concord, affection and firm friendship being established, so that each country would help the other against threats from their parties and conduct mercantile activity freely and securely' (while paying the usual customs duties, however!).

The treaty contained several clauses which emphasised the preservation of French institutions, rights and customs (for example, clauses 8-11). Given Charles's incapacity, Henry was, by clause 7, appointed to the exercise of French royal government until he became king. He was not formally named regent by the treaty. Clause 7 placed the actual exercise of government in his hands or in the hands of others whom he wishes to depute (an implication that he might have to return to England to deal with affairs there) but in practice the title he used from this point onwards was 'heir and regent of France'. He was obliged by the terms of the treaty to rule according to the demands of justice and equity and with the counsel and aid of the great lords, barons and nobles of France (cl. 7). He could not levy taxation without justifying their necessity and observing French custom and practice (cl. 23). Any conquests which he made outside Normandy were to be to the profit of Charles VI (cl. 14), and once the latter was dead, Normandy was to be under the jurisdiction, obedience and monarchy of the French crown (cl. 18). The household of Charles was to be populated only by those born in the kingdom of France or in 'places where French language is spoken' (cl. 27), and Charles was to reside in a notable place within his own obedience - implicitly within France (c1. 28).

The treaty said nothing specifically about preserving English institutions, rights and customs although clause 24 preserved each kingdom in 'its rights, liberties or customs, usages and laws, not subjecting in any way either of the kingdoms to the other, nor the laws, rights, customs, or usages of one realm to the rights, laws, customs or usages of the other'. It was announced at the parliament at Westminster in December 1420 that Henry would now be king of one kingdom and regent and heir to the other. This meant that he would need to spend time in France as well as in England; the decision on this would necessarily be left to "what seemed best to 
his most wise discretion for the better governance of one kingdom and the other'? The central problem of a double monarchy had been broached. Given that it was a personal union, and one person could not be in more than one place at once, the king would be peripatetic. Indeed, the chancellor's opening sermon had explained that the king could not be present at the parliament since he was 'busy in the said parts overseas making good the situation there and working for the greater security of himself and his lieges of England'. This stress on English interests, reinforced by the chancellor's mentioning of Henry's achievements against the Welsh and Lollards as well as his settlement with the French, is important to note and not surprising in the context of other evidence in the parliament on concerns about the treaty.

The commons put forward five petitions relating to the matter. The first was obsequious enough - that the king and his new queen should be requested, encouraged and persuaded to return to England 'with a very short space of time ... for the comfort, relief and support of the aforesaid commons' - but it is significant that it is enrolled immediately after the customary opening common petition confirming the liberties of the church and other lieges. The answer was that 'this is most pleasing to the keeper (gardein) of the realm and he desires it fully' ${ }^{8}$ The commons also petitioned that if the king returned during this or any future parliament, there would be no need for a dissolution or a new assembly. ${ }^{9}$ This also was agreed. They also successfully petitioned that there should be confirmation of the statute of Edward III which had been made in the parliament of 1340 following his adoption of the title 'king of France'. This statute granted that the English should never be subjects of the king of England in his capacity as king of France. This therefore gave the same protection to English institutions in practice and in theory as did the treaty of Troyes to the French. ${ }^{10}$

There were two other areas, however, where the commons' concerns were not met. The commons had been told early in the parliament that the petitions which they submitted to Gloucester as protector would not be engrossed before they were sent overseas to the king. They petitioned against this, asking that all such petitions should be 'answered and determined within this kingdom of England during the course of this same parliament'. Any not answered should be deemed invalid. They asked that this same arrangement should apply to all parliaments held in England in the future. This is more significant than it might at first sight appear since it would limit Henry's authority as king of England when absent. The answer was that the king's advice should be sought. ${ }^{11}$ It is also important to note that the commons put

7 Parliament Rolls of Medieval England. LX: Henry V, 1413-1422, ed. C. Given-Wilson (Woodbridge and London, 2005), p. 251, item 7. (Subsequent references to this parallel text edition of the Rolls of Parliament use the abbreviation PROME.)

8 PROME $I X$, p. 254. This was the king's youngest brother, Humphrey, Duke of Gloucester.

9 PROME IX, p. 251, item 7. Their petition is mentioned in the last entry on the roll (p. 260, item 28), but otherwise we might think that the decision had been taken on government initiative.

10 PROME $L X$, pp. 258-9, item 25.

11 PROME IX, p. 260. 
forward another petition that all bills should be submitted to the commons for their agreement and assent but this too was not accepted. ${ }^{12}$

In this context, therefore, we should perhaps be pleased that the double monarch turned out to be an infant who could rule neither kingdom and therefore could effectively have two separate administrations to avoid such difficulties. But back to 1420: clearly Henry considered it important that the treaty should be ratified by as many people as possible. The treaty of Troyes required that the leading citizens and officeholders of France should make an oath to abide by its terms (cl. 13), with the possibility of additional letters of confirmation and approbation from the princes, nobility and others of each realm (clauses 30 and 31). An interesting role was also given to the three estates of both England and France. So that peace between the two kingdoms might be observed in perpetuity and all future obstacles and dissensions be avoided, Henry was to 'endeavour by the exertion of his own might that, with the advice and consent of the three estates of the realms', all difficulties between the two kingdoms should be removed, and the two crowns held by the same person once he or his heirs came to both titles (cl. 24). ${ }^{13}$ In the light of this, it is significant that in both the English parliament and French Estates General, ratification was made only with Henry present. Thus the treaty was not confirmed at the parliament of December 1420 while he was still in France, but at that which followed his return to England in the spring of 1421. On this occasion, faced with the hero of the hour, the commons declared that they found the treaty 'worthy, necessary and useful to both kingdoms and their subjects and indeed to all Christianity'. ${ }^{14}$ The French Estates had - been convoked in Paris on 6 December 1420 in the presence of both Charles VI and Henry in order to give their ratification. The Estates too declared the peace to be 'to the praise and honour of God, and also to the public good and benefit of the king and the kingdom and of all subjects'. ${ }^{15}$ They further swore, on behalf of themselves and their heirs, to observe the treaty in all its respects, and declared that all who did not abide by its terms would be guilty of treason.

These expressions of approval disguise a wide variety of contemporary opinion on the treaty, as found in chronicles and treatises. ${ }^{16}$ There is not space here to explore this or the many other issues raised by the treaty. The key to understanding its dramatic reversal of French policy towards the English is of course the murder of John the Fearless, Duke of Burgundy, on 10 September 1419, in which the Dauphin Charles was closely implicated. With much justification did a Carthusian monk

12 PROME LX, p. 258.

13 It was also laid down that there could be no negotiation with the so-called Dauphin without the consent of Charles, Henry and Philip of Burgundy as well as of the three estates of each realm (cl. 29).

14 PROME IX, pp. 278-9.

15 Rymer X, pp. 30-32.

16 See, for instance, the English reactions discussed in Anne Curry, 'Le traite de Troyes (1420). Un triomphe pour les Anglais ou pour les Français?', Images de la Guerre de Cent Ans: actes du colloque de Rouen, eds D. Couty, J. Maurice anḍ M. Guéret-Laferté (Paris, 2002), pp. 18-26. For French responses see, for example, 'L'Honneur de la couronne de France': quatre libelles contre les Anglais (vers 1418-vers1429), ed. Nicole Pons (Paris, 1990) and Christopher T. Allmand, Henry V(London, 1992), pp. 149-50. 
show Francis I the skull of John the Fearless in 1521, with the alleged comment 'My lord, that's the hole through which the English entered France'. ${ }^{17}$ The story may be apocryphal but it reminds us of the importance of tangible symbols. What I want to consider in the rest of this article are some of those connected to the treaty of Troyes, especially those revolving around the dynastic issues which it raised.

When Henry and Charles made ceremonial entry into Paris on 1 December 1420, Duke Philip of Burgundy rode alongside dressed in black, the symbol of mourning. This was a deliberate emulation of earlier ceremonial occasions on which Charles, Duke of Orleans had appeared in mourning clothes as a reminder of the murder of his father, Louis, at the hands of John the Fearless in 1407, and as a public expression of his determination to have revenge. In this context it is worth noting that Charles VI and the Dauphin Louis had apparently ordered Duke Charles and his brothers in October 1413 not to wear mourning clothes since the king and his son were aiming for conciliation. ${ }^{18}$ There was no such desire in December 1420 , since included in the treaty was a ban on any diplomatic approaches or agreements with the 'so-called' Dauphin because of the "horrible and enormous crimes and misdeeds [he has] perpetrated in our realm of France' (cl. 29). The ratification in the Estates General needs to be seen within this context. Shortly after the entry to Paris, Duke Philip and his mother's procureur made formal complaint against the ex-Dauphin concerning his role in the murder of Duke John. This was heard by Charles and Henry in a lit de justice, sitting side by side on the same seat (banc). As a symbolic representation of the preservation of French rights and institutions, the chancellor of France and the first president of the parlement sat at Charles's feet. Nicholas Rolin, avocat for the duke of Burgundy and the dowager duchess, addressed both kings, as did the representative of the University of Paris. But again, as a symbol of French authority within France, it was the king of France who made reply through his chancellor, promising that, with the advice of Henry, king of England, regent and heir of France, justice would be done.

The entry to Paris on 1 December 1420, the first entry of Henry and Charles since the treaty had been sealed in May, had also been orchestrated to provide a visual representation of the treaty terms. As the kings entered the city they did so side by side, with the king of France on the right. ${ }^{19}$ Behind them came, on one side, the brothers of the English king (the dukes of Clarence and Bedford), and on the other Duke Philip of Burgundy. Behind them were the members of their households. The representatives of the church met the procession at a crossroads. At this point there were presented to the two kings the relics of saints which both kings were to kiss. Charles VI turned to Henry V and invited him to kiss the relics first, but Henry touched his cap and gestured that Charles should go first. The difficulty of precedence sorted, Charles kissed first, then Henry. The two kings then entered

17 Beaucourt, Histoire, vol. 1, pp. 177-8.

18 R. Famiglietti, Royal Intrigue: Crisis at the Court of Charles VI, 1392-1420 (New York, 1986), p. 137.

19 La Chronique d'Enguerrand de Monstrelet avec piéces justificatives, 1400-1444, ed. L. Douet-D'Arcq (six vols, Paris, 1857-62), vol. 4, 22-3. See also, Journal d'un Bourgeois de Paris, ed. A. Mary (Paris, 1929), p. 142. 
Notre Dame together and paid their devotions before the High Altar. Only then did they separate, with the king of France and the duke of Burgundy going to the Hôtel St Pol, the residence of the king, and then.to the Hotel d'Artois, the residence of the duke of Burgundy, while Henry and his brothers went to lodge in the Louvre. On the next day, the two queens, Charles's wife Isabeau, and Henry's wife Catherine (who was of course daughter of Charles and his queen), entered Paris and were met by the duke of Burgundy and the English lords. When Catherine entered Paris on 30 May 1422, two ermine cloaks were carried in front of her litter. According to the Bourgeois, the Parisians did not know what to think of this unless it was meant as a symbol of her as queen of England and of France (despite the fact that her husband was still only heir)..$^{20}$

Just as the treaty of Troyes skilfully avoided mention of Henry's existing claim to the throne, so too it dealt extremely carefully with the marriage in order to avoid suspicion that it was through union with Catherine that Henry had become heir. The first clause stated that 'by the alliance of marriage made for the benefit of the said peace', he had become the son of Charles and Isabeau, and would 'honour us and our consort as father and mother as is fitting'. But it was not this situation which made Henry heir, since, as we have seen, the preamble of the treaty emphasises that it was made between Charles as king and Henry as heir. It may have been to preclude any thought that France came as Catherine's dower that the treaty required that she should be given dower 'in the kingdom of England' to the value of 40,000 écus (clauses 3 and 4). Only at Henry's death was she to receive dower in France to the value of 20,000 écus, from the lands which Blanche, wife of Philip VI had held (cl. 5). ${ }^{21}$ The wedding to Catherine was held on 2 June 1420, two weeks after the sealing of the treaty - a further means of ensuring a separation between Henry's heirship and the marriage. The latter was intended to cement peace, but was not the peace itself, much as the marriage of Isabella and Richard II in 1396 had cemented the long truce already entered into. This intention was symbolised at the banquet given in London on 24 February 1421, following Catherine's coronation as queen of England, by a sotelte (contrived table decoration) on which there was a banner with the legend: 'par marriage pur, ce guerre ne dure'. ${ }^{22}$

Even more significant are the clauses in the treaty concerning the succession. As we have seen the treaty gave the crown of France to Henry and his heirs. It did not, however, say that these should be the heirs of his marriage to Catherine. Clause 6 says simply 'le roy Henry et de ses hoirs'. Clause 24 says that the two kingdoms must be ruled by the same person 'that is to say, the person of King Henry while he lives, and thenceforward, the persons of his heirs who successively arise, one after the other'. The emphasis is on the fact that there must only be one ruler. The wording permitted Henry's heir to be his heir general not the heir of his body. Thus should he have no offspring, either by Catherine or any later wife, his eldest brother would inherit. Hence the proximity of the dukes of Clarence and Bedford in the entry to

20 Journal d'un Bourgeois, p. 163.

21 Blanche died in 1398.

22 The Great Chronicle of London, ed. A.H. Thomas and I.D. Thornley (London, 1938), p. 118. 
Paris of December 1420. This also explains the remark in a letter sent by the earl of Stafford in France to his wife in England in December 1419 while the treaty was under negotiation: 'and after the death of Charles, king of France, the crown and government of the realm of France will remain with our lord king and the heirs of his body, and if he has no issue of his own body, the crown and government of France will descend to the brothers of our lord the king'. ${ }^{23}$ Once again, it was not the marriage to Catherine which gave the English the French crown, but the treaty.

But what if the heir of Henry or of his brothers was a woman? There was no reason why a woman could not be Queen Regnant in England. In June 1406 Henry IV had planned to restrict the succession to his English (and his putative French) crown and to 'all other lordships on the other side of the sea' to the male line. ${ }^{24}$ This came about because Henry, as a usurper and descendent of the third surviving son of Edward III, continued to fear rival claims from the descendants of the second surviving son but which had passed through the female line. In the last year of his life, Edward III had proposed an entail of the English crown which precluded inheritance through the female line. ${ }^{25}$ Both kings, however, changed their mind, and reversed their decisions. In Henry IV's case the succession of the female offspring of his sons were specifically mentioned as capable of succession. With the Act of Accord made in the parliament of October 1460, the royal claim of Richard, Duke of York, by descent from the second surviving son of Edward III through the female line was confirmed. ${ }^{26}$ There are strong parallels here with the treaty of Troyes since the agreement was for Henry VI to remain on the throne for the rest of his life, but for his son, despite descent in the wholly male line, to be put aside. The right of a woman to pass on a claim was therefore confirmed, as it was at the accession of Henry VII, although in both 1485 and 1460 military factors played a role, as in 1420. Furthermore, it is fair to say that the right of a woman to succeed as queen in England was never tested in the late medieval period since there was a run of male heirs or, in the case of York, claimants.

In France, however, there was no doubt that the right of a woman to be queen regnant had been removed by decision of an assembly in 1317 , when there was a possible candidate in Jeanne d'Evreux, the daughter of Louis X, who was passed over in favour of her uncle, Philip V. That a woman could not transmit a royal title was in practice confirmed by Philip VI becoming king rather than Edward III. ${ }^{27}$ A theoretical position - the so-called Salic law - was developed in retrospect to justify this, and had received a considerable fillip from the writings of Jean de Montreuil

23 NA, C115, K2/6682 (cartulary of the priory of Llanthony), fol. 130r.

24 PROME VIII: Henry IV, 1399-1413, ed. Christopher Given-Wilson, pp. 341-3 (7 June 1406), and pp. 354-61 (reversal on 22 December 1406). See ibid., pp. 233-4 for the settlement of the crown on Henry IV and his heirs in the parliament of 1404 .

25 Michael Bennett, 'Edward III's Entail and the Succession to the Crown, 1376-1471', English Historical Review, 113 (1998): 580-609.

26 PROME XII: Henry VI, 1447-1460, ed. A. Curry and R. Horrox, pp. 522-3. The statues made in the parliaments of 1404 and 1406 which settled the crown on Henry IV and his heirs were also annulled (p. 525).

27 For discussion see Craig Taylor, 'Edward III and the Plantagenet Claim to the French Throne', in James S. Bothwell (ed.), The Age of Edward III (Woodbridge, 2001), pp. 155-69. 
in the first decade of the fifteenth century. ${ }^{28}$ But the treaty of Troyes allowed for the possibility of female succession. This was realised by certain chroniclers, as the following passage found in the Burgundian chronicles reveals. ${ }^{29}$

It was agreed and concluded that Chärles king of France would give his daughter Catherine
in marriage to Henry, king of England, and alongside that, make him true heir and successor
after his death of all his kingdom, both he and his heirs, thereby excluding his own son and
heir, Charles, duke of Touraine. Dauphin de Viennois, and also annulling the constitution
previously made by the kings of France and their peers after great deliberation, namely
that this noble kingdom should not fall to the succession or possession of a woman. And
even if it happened that King Henry did not have living heirs of the marriage, by the terms
of the treaty, he would remain heir of the crown of France to the prejudice of all the royal
family and collateral lines who in time to come might have been able or ought to have
succeeded by right lineage.

It is often forgotten that the treaty had the effect of excluding not only the Dauphin but also other possible claimants within the French royal family, although it said nothing on this. Should the Dauphin's dispossession as a result of his complicity in the murder of John the Fearless be deemed legal, then the next heir in the male line was Charles, Duke of Orleans, conveniently imprisoned in England at this very point. The claims of other male members of the French royal family had been brought up in negotiations in September and October 1419, but effectively dismissed. ${ }^{30}$

It would seem, therefore, that the treaty had the effect of ending Salic law in France for the future, and also retrospectively since Henry's claim to the French throne derived from his descent from Isabella, daughter of Philip IV. But the wording of the treaty was carefully drawn in order to avoid explicit expression of either point. It was vague, therefore, on both the past and the future. We can only speculate what might have happened in England and France had the only child born to Henry and Catherine been a Henrietta rather than a Henry. Would French reluctance to have a queen, accompanied by the requirement of the treaty that the kingdoms should have

28 Craig Taylor, 'The Salic Law and the Valois Succession to the French Crown', French History, 15 (2001): 358-77.

29 'Fu conclu et accorde ... que Charles, roi de France donroit a Henry, Roy d'Angleterre, Katherine sa fille ... en mariage, et avec ques ce le feroit vray heritier et successeur apres sa mort, de tout son royaume lui et ses hoirs, en deboutant son propre filz et heritier Charles duc de Touraine, Dauphin de Viennois et aussi en adnullant la constitutucion jadis faicte par les roys de France et pers, en grand deliberacion, c'est assavoir que ce noble royaume ne devoit succeder ne appartenir a femme. Et mesmes s'il advenoit que le Roy Henry n'eust hoirs vivans dudit mariage par le moien d'icellui traictie et accord, si demourroit-il heritier de la couronne de France, ou prejudice de tous les royaulx et appartenans qui au temps avenir y povoient ou devoient succeder de droit lignee': Monstrelet, vol. 3, p. 379; Receuil des Croniques et Anchiennes istories de la Grant Bretaigne a present nomme Engleterre par Jehan de Waurin, eds W.L. Hardy and E.L.C.P. Hardy (five vols, London, 1864-91), vol. 2, p. 299; Chronique de Jean Le Fèvre, Seigneur de Saint Rémy, ed. F. Morand (two vols, Paris, 1876-81), vol. 1, p. 384.

30 Paul Bonenfant, Du meutre de Montereau au traité de Troyes (Brussels, 1958), Annexe 4, p. 194 (September 1419), and p. 215 (13 October 1419). 
the same ruler, have effectively forced the English to themselves adopt Salic Law? Fortunately for us, this is counter-factual: Henry VI was at least a boy.

Let us end with some reflections on the symbolic representation of his dual kingship in the years leading up to and including his coronation in Paris in December 1431. While it was possible for Henry V to manifest his heirship in person, this was impossible for Henry VI for quite some time. This leads to a significant redirection in English propaganda on the treaty. Under Henry V the stress was on his acceptance as heir by Charles VI, although deriving from the claim of English kings dating back to Edward III. Under Henry VI the marriage to Catherine was given special emphasis. The stress was on Henry VI's dual descent on his paternal and maternal side. This began slowly. At the first English parliament of the new reign in November 1422 the chancellor noted how God had blessed Henry with 'a most beautiful and most glorious son, begotten of the most honourable blood of France, now king of England and of France'. It was this son who would complete his father's work. This was shown by his being the sixth Henry. Had God not finished all his work in six days, the chancellor opined.

In France a number of chroniclers writing within the areas of English obedience in the 1420s have it that only the male heirs of the marriage between Henry and Catherine could become kings of France. ${ }^{31}$ The earl of Warwick commissioned John Lydgate to produce a poem to accompany a painted pedigree which showed how 'Henry the sixth is true born heir to the French crown by lineal succession both on the side of his father, Henry V, and on the side of his mother, Catherine, queen of England, his mother'. Both the poem and the pedigree survive. ${ }^{32}$ The prologue begins with its purpose "troubled hearts to quiet ... of those who dispute in their opinions touching the royal line of two areas, the right I mean of England and of France'. Lydgate tells us that for the main part of his work he was in effect translating into English from an existing French work by Laurence Calot. The French text is not known to have survived, but given Lydgate's comments, it undoubtedly pursued the same line of argument. Indeed the painted pedigree is certainly the work of a French artist.

In both the English and French works, therefore, Henry VI was emphasised as descended from the blood of Saint Louis in two respects, through his mother and through his father - a double inheritance. In addition, he is described as 'an heir of peace by just succession' ... justly born, to remove all dispute, to be king of England and of France'. There is no reference at all to the treaty as the source of his kingship. The marriage of Henry and Catherine is mentioned three times. A direct link is also made between Henry and his grandfather, Charles VI. The painted pedigree paralleled Henry's descent from Saint Louis with the descent on his paternal side

31 'Apres toutes ses choses, apointment fu fait du roy de cheux de Paris qu'il aroit la fille du roy a mariage, et seroit gouverneur general de Franche, et seroit roy apres la mort du dit roy pour lui et pour ses heirs ou cas ou elle aroit her maale de lui yssant': Chronique Normande de Pierre Cochon, ed. C. du Robillard de Beaurepaire (Rouen, 1870), p. 283. See also Mémoires de Pierre de Fenin, ed. L.M.E. Dupont (Paris, 1837), p. 137: 'sans que jamais nul venant du coste du roy Charles y peust venir, s'il ne yssoit du roy Henry et de Katherine'.

32 Political Poems and Songs relating to English History, ed. T. Wright (two vols, London, 1859-61), vol. 2, pp. 131-40. 
from the sainted king, Edward the Confessor. This was not mentioned in Lydgate's poem, no doubt because it was largely a translation from a French work. But in another poem written for the king's coronation at Westminster on 6 November 1429, this double descent from two saints took pride of place. Later in the poem Henry's immediate parentage is provided as a guide to him ("your father which did so shine in all virtue ... with the good life of queen Catherine, your blessed mother ... of good roots, springing from virtue must grow good fruit by necessity'). There was also mention of the king's descent from Clovis to whom the angel had brought the fleur-de-lys of gold, 'to signify ... perfect belief and steadfast unity of three persons in the Trinity; in order to declare that the line of France should in their truth perfect and stable be, grounded in faith without variance' ${ }^{33}$

By this point in time, the traditional crowning place of Reims had fallen to Charles VII who had thus been anointed with the oil of Clovis in his coronation on 17 July 1429. It proved impossible for the English to recover the city over the next two years, yet it was imperative to have the young Henry crowned as king of France, even if at Paris. The orchestration of his entry to the capital included a tableau at the Chatelet: a boy resembling the king clothed in fleur-de-lys had two crowns on his head. To his right stood actors dressed as the duke of Burgundy and the count of Nevers, who presented him with the shield of France. To the left stood actors dressed as the duke of Bedford and the earl of Warwick who presented the shield of England. There is no doubt that this entry was orchestrated to provide a direct link to his father's entry to Paris as heir of France in December 1420. Both Henrys deliberately entered the city on Advent Sunday - a symbol of the coming of the king. ${ }^{34}$ At the time of Henry VI's French coronation, therefore, the emphasis on the double monarchy persisted, as exemplified by the emulation of Henry V's royal entry, but the role of Catherine as queen mother was downplayed: she did not attend her son's coronation as king of France. With Charles VII crowned, the English needed to link Henry's kingship back to the inheritance created by the treaty of Troyes, not the marriage. Furthermore, it is possible that Catherine was pregnant with a child by Owen Tudor and hence perhaps less a tangible symbol of 'a good life' than she had earlier been.

With hindsight, we know that the writing was already on the wall for the double monarchy at the point Henry was crowned in both of his kingdoms. Divine support for Charles VII had been revealed through his military successes and his coronation at Reims. This in turn gave credibility to a counter view which had circulated in France right from the time of the treaty, namely that it was not possible for a king to change the succession. As one text put it, 'a king could not prejudice the heir which came of his own flesh nor alienate the kingdom to another, but that the crown had to go to the person to whom it should descend by hereditary succession' ${ }^{35}$ The French

33 Ibid., vol. 2, pp. 141-2.

34 Guy L. Thompson, Paris and its People under English Rule: the Anglo-Burgundian Regime 1420-1432 (Oxford, 1991), p. 193; Anne Curry, "The "coronation expedition" and Henry VI's court in France, 1430-1432', in Jenny Stratford (ed.), The Lancastrian Court: proceedings of the 2001 Harlaxton Symposium (Donnington, 2003), pp. 29-52 at p. 44.

35 'Traictie compendieux de la querelle de France contre les Anglois', quoted in Peter S. Lewis, Later Medieval France: the Polity (London, 1968), p. 95, n. 2. 
were to abide by this principle for the rest of the ancien régime, while the English operated rather looser dynastic practices, although even those with the most dubious title to the English throne continued to call themselves monarchs of France. The treaty of Troyes was never formally rescinded. The English remained kings of France until France no longer had a king to pretend to be: the title was finally abandoned at the point of negotiating the treaty of Amiens with Napoleon in 1801-02. Had the treaty of Troyes worked, the 'united kingdom' would have been England and France rather than England and Scotland, the history of Britain, France and Europe would have been very different.

\section{Appendix}

\section{The Treaty of Troyes, 21 May 1420}

Charles, by the grace of God, king of France, in perpetual memory. Whereas several notable treaties, aimed at the re-establishment of peace and removal of dissensions between the kingdoms of France and of England, were made in the past between our noble progenitors of happy memory and those of the most high prince and our very dear son, Henry, king of England, heir of France, and also between us and our said son, but which have not brought the fruit of peace so desired, be it known to all present and to come that we, considering and weighing in our hearts how many great and irreparable evils, how many enormities and what wretched and incurable universal sorrow have been caused by the division of the two kingdoms to this point, not only for the kingdoms themselves but for all the church militant, we have made treaty of peace with our son Henry. After many discussions and deliberations by the men of our great council, this treaty, which gives effect to our desires and which promises peace to men of good will, is concluded and agreed between us and our son in fulfilment of the desired peace, in the manner which follows:

1. First, that since by the alliance of marriage made, for the benefit of the sat peace, between our son, King Henry, and our most dear and beloved daughter, Catherine, he has become son of both us and our most dear and beloved consort [compagne], the queen, our son will hold and honour us and our consort as father and mother as is fitting, as such great princes and princesses and before all other temporal persons in this world.

2. Item, that our said son, King Henry, shall not disturb, hinder or prevent us from holding and possessing for as long as we live, and as we hold and possess it at present, the crown and royal dignity of France, with the revenues, fruits, and profits thereof, for the sustenance of our estate and the costs of the kingdom, and that our consort shall also hold, for as long as she lives, the estate and dignity of queen according to the custom of our said country, with the share of the said rents and revenues appropriate for her. 
3. Item, it is agreed that our said daughter Catherine will have and take in the kingdom of England a dowry as the queens of England have been accustomed to have in the past, that is to say, for every year the sum of 40,000 écus (with two écus being the equivalent value to one English noble).

4. Item, it is agreed that, by all ways, means, and methods that he can, without transgressing or offending against the oath he makes to observe the laws, customs, and rights of his English kingdom, our said son, Henry, shall endeavour and provide that as soon as possible our said daughter, Catherine, his consort, shall be fully assured of taking and having in his kingdom of England from the time of his death the dowry aforesaid of 40,000 écus (with two écus being the equivalent value to one English noble).

5. Item, it is agreed that if our said daughter should survive our said son King Henry she shall take and have from the kingdom of France dowry of 20,000 francs a year beginning immediately after the death of our said son, from the lands, places, and lordships which were held and possessed in the same form of dowry by our dear lady of blessed memory, Blanche, formerly wife of King Philip [VI], our most dread lord and great grandfather.

6. Item, it is agreed that immediately after our death and thenceforward, the crown and realm of France and all their rights and appurtenances shall remain and perpetually be with our said son, King Henry, and his heirs.

7. Item, forasmuch as we are withheld and hindered most of our time in such a way that we cannot personally deal with or attend to the disposition of the business of our said realm, the faculty and exercise of governing and ordering the public business (la chose publique) of the said realm shall be vested in and remain during our life with our said son, Henry, with the counsel of wise and noble men in our obedience who are devoted to the profit and honour of the kingdom, so that from this time forward he can rule and govern by himself and by others whom he wishes to depute, with the counsel of the wise and noble men aforesaid. Which power of governing being thus vested in our said son, King Henry, he shall work lovingly, diligently and faithfully for what may and should be for the glory of God, of us, and of our consort, and for the public good of the kingdom, and to defend, make tranquil, pacify, and govern it according to the demands of justice and equity, with the counsel and assistance of the great lords, barons and nobles of the said realm.

8. Item, that our said son shall labour with all his might, that in each and every place subject to us now and in time to come, the court of the parlement of France shall be preserved and protected in the sovereignty and authority belonging to it and due to it in each and every place subject to us now or in the future.

9. Item, that our said son shall labour with all his might to defend and preserve each and every one of the peers, nobles, cities, towns, communities, and individuals subject to us, now and at all times to come, in the rights, customs, privileges, 
prerogatives, liberties, and franchises appertaining or due to them, in all places subject to us now or in the future.

10. Item, that our said son shall diligently and loyally labour with all his might that justice be administered in the said realm according to the laws, rights, and customs of the same, without exception of persons, and shall preserve and keep the subjects of our realm in peace and tranquillity, and labour with all his might to guard and defend them from all oppression and violence whatsoever.

11. Item, it is agreed that our said son, King Henry, shall make provision and labour with all his might to ensure that to the offices, whether of justice, of parlement or of bailliages, seneschausées, prévôtés and others pertaining to the government of his seignory, and also all other offices of the realm, there shall be appointed able, suitable and advantageous persons, for the good, just, peaceful and tranquil government of the realm and the administrations which are committed to them, and that they are such men as should be deputed and appointed according to the laws and rights of the realm, and for the profit of us and our realm.

12. Item, that our said son shall labour with all his might, and as soon as profitably can be done, to put in our obedience all the cities, towns, countries, castles, places, areas and persons within our realm which are disobedient to us, and rebels holding to or being of the party commonly called that of the Dauphin and of Armagnac.

13. Item, in order that our said son may be able the more profitably, securely, and freely to accomplish and effect the things abovementioned, it is agreed that the great lords, barons, and nobles, and the estates of the said realm, both spiritual and temporal, also the cities and notable communities, and the citizens and burgesses of towns in the said realm subject to us at the time, shall take the oaths which follow.

First, to obey and observe humbly and in full obedience in all respects our son, King Henry, having and exercising the power of governing the chose publique, and to his commands and orders in all matters concerning the exercise of the government of the realm.

Item, that the said great lords, barons and estates of our realm, spiritual as well as temporal, and also the cities, notable communities; citizens and bourgeois of the towns in the said realm, insofar as they and each of them are concerned, shall in all things and everywhere well and faithfully keep, and with all their might have kept by everyone else, the things which are and shall be appointed and agreed between us, our consort the queen, and our son, King Henry, with the counsel of those who we, our consort, and our said son shall have appointed thereto.

Item, that continually from the time of our death and afterwards they will be faithful men and lieges of our son, King Henry, and his heirs, and they will hold this our son as their sovereign liege lord and the true King of France, and without any opposition, contradiction, or difficulty will receive and obey him as such; and that after this, they will never obey any other than us as king and regent of the realm of France, unless our son King Henry and his heirs. 
Item, that they will not counsel, aid or give consent that our son king Henry lose life or limb, or be taken by heinous act of capture, or suffer damage or diminution in his person, estate, honour, or possessions, but that if they know that any such thing is being plotted against him, or planned, they will prevent it with all their power and inform him as soon as they can by messages or letters.

14. Item, it is agreed that each and every conquest which shall be made by our said son, King Henry, outside the duchy of Normandy in the realm of France from those who are disobedient to us shall be made for our benefit, and that our said son shall labour with all his might that each and every of the lands and lordships in places thus to be conquered, pertaining to persons now obedient to us who shall swear to observe this present agreement, be restored to the said persons to whom they belong.

15. Item, it is agreed that each and every beneficed ecclesiastic in the duchy of Normandy, or any in other places whatsoever in the realm of France, subject to our said son, obedient to us and favouring the party of our very dear son the duke of Burgundy, who shall swear to observe this present agreement, shall peaceably enjoy their ecclesiastical benefices in the duchy of Normandy and in the places aforesaid.

16. Item, that each and every ecclesiastic obeying our said son, King Henry, having benefices in the realm of France in places subject to us, and who shall swear to keep this present agreement, shall peacefully enjoy their benefices in the aforesaid
places."

17. Item, that each and every of the churches, universities, studium generale, schools, colleges of students and other ecclesiastical colleges situated in places subject to us now or in time to come in the duchy of Normandy or other places in the realm of France subject to our son, King Henry, shall enjoy their rights and possessions, rents, prerogatives, pre-eminences and franchises in the realm of France, however belonging to them or due, saving the rights of the crown and of all others.

18. Item, when it shall come to pass that our said son, King Henry, comes to the crown of France, the duchy of Normandy and likewise all and each of the places conquered by him in the realm of France shall be under the jurisdiction, obedience,
and sovereignty of the crown of France.

19. Item, it is agreed that our said son, King Henry, shall with all his might labour that to the persons obedient to us and favouring the aforesaid party called Burgundian to whom belong lordships, lands, revenues, and possessions in the duchy of Normandy or other places in the realm of France which have been conquered by this our son, King Henry, and already by him given away, there shall, without diminution of the realm of France, be compensation made by us from the places and lands acquired or to be acquired in our name from those rebellious and disobedient to us; and if this compensation is not made in our lifetime, it shall be for our son, King Henry, to effect it in lands and goods when he shall succeed to the crown of France. But if the lands, lordships, rents, and possessions which belonged to the said persons in the 
duchy and places above-named have not been given away by our said son, the said persons shall be reinstated in them without delay or opposition.

20. Item, that during our life, in all places now or in time to come subject to us, the common letters of justice, gifts of offices, benefices and other donations, pardons, remissions, and privileges, shall be written or issued under our name and our seal. Nevertheless because some specific cases might arise which cannot be forseen by human insight, and in which it may be necessary and fitting that our son, King Henry, should cause his own letters to be written, in such cases, if any occur, it shall be lawful for our said son, for the well-being and security of us and of the government belonging to him, as has been said above, and to avoid the dangers and mischiefs which might otherwise be likely to happen, to write to our subjects his own letters, by which he shall command, forbid and order on our behalf and on his own as regent, according to the nature and quality of the business.

21. Item, that during our lifetime our said son King Henry shall not call himself, or describe himself in writing, or cause himself to be called or described in writing as King of France but shall entirely abstain from this title for as long as we live.

22. Item, it is agreed that during our life we shall name, call, and write of this our son in the French language in this manner: nostre tres cher fils, Henry roy d'Angleterre, héritier de france, and in Latin, 'noster precarissimus filius Henricus Rex Anglie, heres Francie' (Our most beloved son Henry king of England, heir of France).

23. Item, that our said son shall not impose, or cause to be imposed, any burdens or exactions on our subjects without reasonable or necessary cause, and for the public good of our realm of France and according to the order and requirement of the laws and the reasonable and agreed customs of the realm.

24. Item, in order that peace and tranquillity may be perpetually preserved for the time to come between the two realms of France and England, and to prevent the difficulties and occasions within which debate, dissension or discord might arise in future between the two realms, which God forbid, it is agreed that our said son shall endeavour by the exertion of his own might, that, with the advice and consent of the three estates of the realms - the obstacles in this respect being removed - it be ordered and provided that from the time that our son or any of his heirs shall succeed to the crown of France, the two crowns of France and England shall for ever remain together and shall be vested in one and the same person, that is to say, in the person of our said son, Henry, King of England, whilst he lives, and thenceforward in the person of his heirs who shall successively arise one after the other; and that the two realms shall be governed from the time that our said son or any of his heirs shall come into the above-named realms, not separately under different kings at the same time, but under one and the same person who shall be at the time king and sovereign lord of both realms as is said, saving always in all other respects to each realm its rights, liberties or customs, usages, and laws, not subjecting in any way one of the 
said realms to the other, nor the laws, rights, customs, or usages of one realm to the rights, laws, customs or usages of the other.

25. Item, that from now and for all time in perpetuity all divisions, hatreds, rancours, wars, or questions between the two realms and their peoples adhering to the said agreement shall be silenced and appeased, and in all points cease, and between the said two realms from henceforth forever peace, tranquillity, affection, mutual agreement, firm and stable friendship shall be in force; and the two realms shall help each other with their aid, counsel and mutual assistance against all persons that would endeavour to do violence, wrong, or injury to them or either of them, and they shall frequent and trade with each other faithfully, paying the customs and obligations which are due and accustomed.

26. Item, that all the confederates and allies of us and of our realm of France, and also all the allies of our son, King Henry, and of the realm of England, who, within eight months after this present agreement of peace is notified to them, declare themselves willing firmly to adhere to it and to be included in the treaty and agreement of the peace, shall be included in the alliances and confederations, sureties and agreement of the peace, saving always to both realms and their subjects any actions, rights, and remedies whatsoever proper in this behalf in actions against the said allies and confederates.

27. Item, it is agreed that our said son, King Henry, with the advice of our very dear son, Philip, Duke of Burgundy, and the other nobles of the realm of France to whom it pertains to be summoned thereto, shall provide for the government of our person safely, befittingly, and decently, according to the requirements of our estate and royal dignity in such manner as shall be for the honour of us and also of the realm of France and the subjects thereof; and that all persons, both nobles as others, who shall be about us for our personal and domestic service not only in offices but also in other mysteries shall be such as shall have been born in the realm of France, or in places where the French language is spoken, good persons, wise, loyal, and fit for the said service.

28. Item, that we will remain and reside personally in a significant place within our obedience and not elsewhere.

29. Item, considering the horrible and enormous crimes and misdeeds perpetrated in our realm of France by Charles calling himself dauphin of Viennois, it is agreed that we, our son, King Henry, and also our very dear son, Philip, Duke of Burgundy, will not in any way treat for peace or agreement with the said Charles or cause him to be treated with unless by consent of each and every one of us and of the three estates of the said realms.

30. Item, it is agreed that besides our letters patent concerning the things above set forth, and each of them, we shall give and cause to be given to our son, King Henry, letters patent of approbation and confirmation from our consort the queen, our son 
the duke of Burgundy, and others of our royal blood, from the great lords, barons, cities, and towns subject to us from whom in this respect our son, King Henry, may wish to have letters.

31. Item, that in like manner our son, King Henry, on his part, besides his letters patent for these said things sealed with his great seal, shall cause to be given and made for us letters patent also of approbation and confirmation from his very dear brothers, from the other great lords of his royal blood, from the great lords, barons, and cities and towns within his obedience from whom in this respect we desire to have letters of our son, the King of England.

Each and every one of the things above written, we, Charles, King of France, for ourselves and our heirs, insofar as it can effect us and our heirs, without fraud or evil design, have promised and do promise, have sworn and do swear on the word of a king and upon the holy gospels of God personally touched by us, to effect, accomplish and observe, and make our subjects effect, accomplish and observe, and also that neither we nor our heirs shall ever act to the contrary to the things abovementioned or any of them in any manner or fashion that may be, in judgment or out of judgment, directly or indirectly, or by any manner of excuse whatever. And in order that all these things, and the articles above-mentioned, may be firm and stable continually and forever we have caused our seal to be put to these present letters. Given in our town of Troyes the 21st day of the month of May in the year 1420 and of our reign the fortieth. Thus signed by King Charles in his council. 